\title{
Primary carcinoma of the trachea: mixed squamous and oat cell type
}

\section{P E THORNLEY AND $S$ R HOWATSON}

From the Chest Unit, City Hospital, and Department of Pathology, University of Edinburgh, Edinburgh

Primary carcinoma of the trachea is a rare neoplasm. In a combined multicentre series only two primary carcinomas of trachea were found in 47600 necropsies. ${ }^{1}$ In 30 years at the Mayo Clinic 47 primary carcinomas of trachea were diagnosed. ${ }^{2}$ These included 24 squamous carcinomas, which was the commonest histological type, but only two oat cell tumours.

We report a case of primary carcinoma of trachea with an unusual mixed histological pattern of oat cell and squamous cell type. This mixed cellular pattern was also seen in varying proportions in metastases at different sites.

\section{Case report}

The patient, a 60-year-old man, had had increasing breathlessness on exertion for over six months, which eventually limited his walking to about $270 \mathrm{~m}$ on level in weight over the six months. At presentation there was faint stridor but no finger clubbing or cervical lymphadenopathy.

The chest radiograph was normal but tomography showed the tracheal tumour $5 \mathrm{~cm}$ above the main carina and a right-sided paratracheal mass which later proved to be a lymph node containing metastatic tumour.

At thoracotomy, the tracheal tumour was removed in continuity with the enlarged, paratracheal nodes and the defect repaired with a pericardial patch. Staphylococcal bronchopneumonia developed on the third postoperative day and, despite intensive treatment, the patient died 18 days after operation.

\section{PATHOLOGY}

The resected specimen was an ellipse of tracheal wall, with an ulcerated nodular tumour mass $2 \times 1.8 \times 1 \mathrm{~cm}$

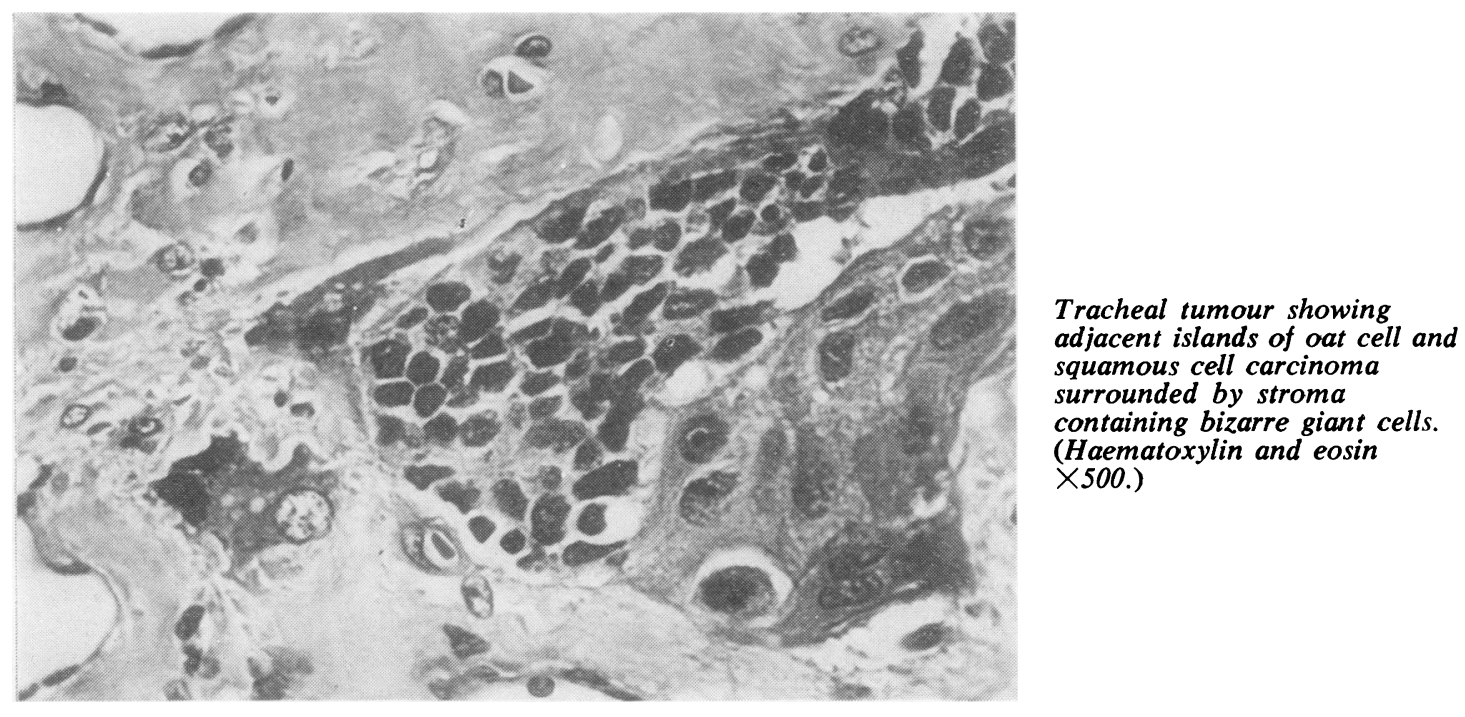

ground. He had smoked 30 cigarettes daily for about 40 years and had chronic morning cough and sputum. Recently the cough had persisted during the day and, at night, was associated with paroxysms of breathlessness. There had been streaky haemoptyses in his usual mucoid sputum for several weeks. He had lost $19 \mathrm{~kg}$

Address for reprint requests: Dr SR Howatson, Department of Pathology, University of Edinburgh, Edinburgh. on the inner surface. The nodule consisted of islands of oat cell carcinoma separated by a prominent stroma that included bizarre tumour giant cells. There were occasional small foci of squamous carcinoma in close proximity to the islands of oat cell tumour (figure). Typical oat cell carcinoma infiltrated the tracheal wall.

Lymph nodes, also resected, were widely infiltrated by oat cell tumour and contained islands of squamous 
carcinoma. These had the appearance of separate metastases rather than squamous differentiation within oat cell tumour.

At necropsy bronchopneumonia with focal areas of infarction and necrotising inflammation of the airways was present. The lungs were fixed by inflation with formalin and, on section, there was no evidence of tumour. Widespread metastases were found in lymph nodes, liver, lumbar vertebrae, ribs, right adrenal, right kidney, and ureter and showed varying histological patterns. Some were pure oat cell tumour, others were pure squamous carcinoma, and yet others showed a mixed picture.

\section{Discussion}

The clinical features of this case, which included breathlessness, cough, haemoptysis, and stridor are typical of a tracheal neoplasm. ${ }^{3} \mathrm{~A}$ normal chest radiograph is commonly found while tomography is often diagnostic ${ }^{2}$ and in this case was useful in showing the position and extent of the primary tumour and paratracheal mass. The importance of bronchoscopy in a patient complaining of respiratory symptoms and having a normal chest radiograph has been recognised previously ${ }^{4}$ and is again shown. Although major obstruction of a large airway was suspected, a firm diagnosis of tracheal occlusion was not made until the tumour was seen at bronchoscopy.

The histology of this tracheal tumour is unusual and no similar case has been reported previously, although a mixed squamous and oat cell pattern is well recognised in bronchial carcinoma. ${ }^{5}$ In this case the two cell types were well demarcated and also remained separate in the lymph node metastases. Metastases elsewhere were either of oat cell or squamous cell nature. In addition the primary tumour had a well-developed stromal component in which giant cells were prominent. Oat cell tumours rarely have any significant stroma whereas this is often prominent with squamous carcinomas. In the latter the spindle cells of the stroma have been shown to have an epithelial origin, and in this case the stromal giant cells are probably of squamous carcinoma origin.

This tumour is of epithelial origin but shows an unusual mixed oat and squamous cell histological pattern that is reproduced in varying proportions in the metastatic deposits.

We thank Dr NW Horne and Mr RJM McCormack for permission to publish this case and Dr D Lamb for his help in preparing the report.

\section{References}

1 Culp OS. Primary carcinoma of the trachea. J Thorac Surg 1938; 7:471-87.

2 Houston HE, Payne WS, Harrison EG, Olsen AM. Primary cancers of the trachea. Arch Surg 1969; 99:132-40.

3 Moersch HJ, Clagett OT, Ellis FH. Tumors of the trachea. Med Clin North Am 1954; 38:1091-6.

4 Lewit T, Karman S, Terracina, S, Beemer AM. Malignant tumors of the trachea. Chest 1971; 60: 498-9.

5 Yesner R. Spectrum of lung cancer and ectopic hormones. In: Sommers SC, Rosen PP, eds. Pathology Annual, part 1. New York: Appleton-Century-Crofts, 1978:219. 